\title{
Training of Foreign Trade-Oriented Business English Major
}

\author{
Lu Sun \\ Harbin University of Commerce, Harbin, China, 150028 \\ SUN_LU1980@163.com
}

Keywords: Business english; Foreign trade demand; Talent training; Curriculum design

\begin{abstract}
Business English is a very strong pertinence, practicality and the characteristics of the times of the professional. With the rapid development of information technology and the acceleration of global economic integration, the training model of business English professionals in China is facing new challenges. With many years of practical experience in foreign trade, to the current our country college business English professional talent training some problems existing in the process are analyzed deeply. Based on about how to improve these problems and to improve the quality of talent cultivation are discussed.
\end{abstract}

\section{Introduction}

China's accession to the WTO has brought great opportunities to the economic development of our country society needs a large number of high-quality talents of business English, and on their proposed higher requirements: not only have rich professional knowledge, good command of a foreign language level, skilled use of network technology, and master the WTO rules. As the training of high quality talents in Colleges and universities, the creation of business English major courses for the country to cultivate a large number of both professional and skilled master business English talent, but also to adapt to the new requirements of economic development. Under the current economic globalization and the rapid development of the information industry, the teaching of business English Majors in Colleges and universities is facing new challenges.

\section{The Concept of Business English}

The so-called business English refers to people in business activity by use of English, comparative exactly said that business English should include ordinary commercial English, OLS commercial English) and specialized business English (specialized commercial English). Thus, business English is not an independent language, it is still English, is the use of English in the context of international business. Business English and general English has a close contact, but compared with the ordinary English it has distinctive features, showing a strong industry characteristics, involved in the industry, including: international trade, international finance, international accounting, international transportation, international commercial law, insurance, banking, economics, marketing, logistics, business management, business services and other.

\section{"Complex" Business English Talent Demand and Status Quo}

After China's accession to the WTO, domestic production enterprises can be directly exported to foreign countries for their own products, without the need for the trading company to operate; with the continuous development of social economy, people all over the world business communication is increasingly close, more and more people to enter the foreign work, English has gradually become most widely spoken language in the tools of communication in the world. Regardless of their nature of work and how the environment, they must communicate with foreign, language differences is undoubtedly the biggest obstacle encountered by these people, and business English is to become the kind of foreign business people between the most important tool of communication. From the supply and demand situation of foreign talent market in recent years, the demand for pure English language professionals is declining year by year. And past due to a shortage of foreign 
language talents, people excessively emphasizes the status of languages in their overall ability and quality, now need foreign is both good language foundation, but also has high professional quality of composite talents in the industry. This not only understand the language of understand and professional generalist is becoming increasingly popular.

\section{Compared with Foreign Trade Practice, the Lack of Business English Teaching in Colleges and Universities}

Business English majors because of its particularity, it emphasizes the combination and application of business knowledge and English language ability. Its purpose is to cultivate more suitable for the needs of the new era of economic development of the professional, is a targeted, strong practical professional. Therefore, the teaching of business English majors should be advanced and practical, and should be fully developed and practical teaching links. At present, in the curriculum design of business English in Colleges and universities (or related field), mainly for language skills and general background knowledge of business and general business environment using the cultivation of language ability and professional is not strong. From the Harbin University of Commerce of the 2014 edition of the English (Business English) teaching plan, I see the curriculum exists some deficiencies, it put emphasis on cultivating is English language and English listening, speaking ability, relatively speaking, a business course is much less; for example, the foreign trade import and export documents, electronic commerce and the customs declaration, inspection practices this kind of course, there is no set or relative set is relatively small. At present, China's foreign trade process has been adopted in the form of electronic. The author believes that these content is updated in real time, in the whole process of foreign trade accounted for a very heavy role. You can also see from the teaching plan, the allocation of practice links exist some shortcomings, the business English professional class to 2920 hours, practice link accounted for $16.7 \%$ in the whole teaching assignments, 173 hours, of which about the international trade practice teaching accounted for only about 10 percent of the practice teaching.

Teaching materials of business English Majors in Colleges and universities, there are also relatively backward problems. In the 1990s textbooks are now some of the courses are still in use today. For some of the newer knowledge, such as customs, Ministry of Commerce announced the new policy, the state on the export tax rebate updates and so on, there is no timely to keep up with, resulting in closed for some students to enter the society. In some small and medium enterprises, foreign trade may only one or two people in the operation, which also increases the pressure of employment, the request of the enterprise is higher, not only require you to have a good command of a foreign language level, asking you to have certain professional knowledge, and the flow of foreign trade to skilled. Just graduated from college students, not a little practical experience, only from books to learn a little something, the company's production simply do not understand, not to mention the use of Internet search customers, to carry out foreign trade business. And the company can teach, only the production of technical terms and some of the production related knowledge, other things must be their own exploration, experience must be a little bit of accumulation. In the actual operation of the process generated a lot of problems, such as how to find potential customers through a variety of channels, from the Internet to find customers? If there are overseas customers to send you a fax, EMAIL on your company's products, this offer is reasonable, the offer is reasonable; customers are willing to accept, from potential customers into real customers? Can directly to the domestic sales price as the basis for the conversion of foreign exchange, the customer needs what price on the set of formulas? The product of the international market price level, the trend of how? Then, for example, the customer orders a product from your company, he used what payment methods, how can we negotiate with the customer for their use of the payment method? How to carry out the product after the production is finished in the production department? Which materials and documents are required for customs declaration? Freight forwarding company's goods, the bill of lading has what requirements? Need to perform inspection of product inspection procedures? For insurance company's insurance policy, the bill of lading of the shipping company, 
whether the customer has special requirements? These problems are not previously studied in college textbooks or learn more.

\section{How to Develop the Talents Training of Business English Major in University}

The curriculum of business English majors should not only pay attention to the professional knowledge, but also pay attention to the perfect combination of the professional direction. First of all, the professional basic course of business English major should be deepened, and the training of listening, speaking, reading and writing ability should be strengthened. English professional knowledge is the future of students based on the social basis, the foundation of a good, learning the knowledge of business is much easier. Secondly, the general mathematics foundation for business English Majors in Colleges and universities is weak, and the requirements of the business majors are not low. The overall curriculum of business English majors also makes some corresponding adjustments, and expands the choice scope of the specialty elective course. For students to provide opportunity to choose the direction of development, the realization of the personnel training diversification and people-oriented, individualized teaching mode. For the teaching of business English Majors in Colleges and universities should increase foreign trade import and export documents, electronic commerce and the customs declaration, inspection practice, especially the contents of the documents and the actual operation, the knowledge of customs practice should pay attention to timely updates and additions. In order to adapt to the requirements of the development of the new situation. Once again, we should strengthen the practice of business English, in teaching content increase to give students hands-on case, to let the students grasp more professional skills, give students create all opportunities to practice, and use good winter and summer, let students more contact with the community, understand the community, strive to let them become a compound talents, so as to in the future job markets become experts.

\section{Conclusion}

Through the study of College English teaching, business English in Colleges and universities teaching and put forward some opinions and suggestions, in order to improve training in line with the requirements of the economic development under the new situation of business English talents.

\section{Acknowledgements}

This paper is supported by Philosophy and Social Scientific Research Project Foundation of Heilongjiang Province (No.14C009). At the same time this paper is supported by the Higher Education Reform Project （No.JG2014010815）of Heilongjiang Province.

\section{References}

[1] Avery. G. C, Leadership for Sustainable Futures Achieving Success in a Competitive World, first ed., Edward Elgar, 2013.

[2] Bacon. C. S, Enhancing Critical Thinking Skills through Conversation in the Classroom, J. Sci. Commun. 11 (2011) 178-179.

[3] Cottrell. S, Critical Thinking Skills: Developing Effective Analysis and Argument, first ed., American Irwin, 2012.

[4] Cowen. T, Creative Destruction: How Globalization is changing the World's Cultures, first ed., Princeton University Press, 2012.

[5] Elsa Dent, The Leadership Pocketbook, first ed., Management Pocketbooks, 2003.

[6] Michalak. S. J, Liberal Education, J.Sci.Commun.156 (2013) 78.

[7] Quilliam. S, Positive Thinking, third ed., United States: DK Publishing, New York, 2012. 
[8] Stamm. B. V, Managing, Innovation, Design, and Creativity, third ed., John Wiley \& Sons Ltd, Washington, 2013.

[9] Taylor. W. M, Informal Logic, J. Sci. Commun. 10 (2012) 19-22.

[10] Thompson. J. N, On Being a Successful Graduate Student, first ed., University of California, 2011. 